\title{
microRNA-21 and Its Emerging Role in Tumor Progression in Systemic Malignancies
}

\author{
Shailendra Kapoor \\ Mechanicsville, VA, USA
}

To the editor:

The recent article by Ozgün et al. [1] provided for highly interesting reading. MicroRNA-21 (miR-21) may contribute to tumor progression and prognosis in a number of other gastrointestinal malignancies.

For instance, similar effects are seen in colorectal malignancies. It regulates TGF $\beta$ R2 signaling in the malignant colonic tissue [2]. As a result, it modulates cancer stem cell function in colon tissue. Typically, miR-21 expression is accentuated in malignant colonic tissue [3]. An inverse relationship exists between miR-21 expression and the expression of Sprouty 2 protein in the colonic cancerous cells [4]. miR-21 also modulates Cdc25A function and thereby further contributes to tumor progression in colorectal malignancies [5]. miR21 also has a negative impact on PDCD4 mRNA levels within the cancerous cells [6]. Subjects with stage II colon cancer with accentuated miR-21 expression within the colonic stroma tend to have decreased disease free survival [7]. A similar negative impact is seen on overall survival. Interestingly, the anti-proliferative effects of chemotherapeutic agents such as 5-fluorouracil is markedly accentuated secondary to the modulatory effects of miR-21on the expression of Sprouty2 protein [8]. Increased PTEN expression is also seen.

A similar impact is seen in gastric malignancies. miR-21 expression is typically accentuated in gastric carcinomas. This in turn results in decreased expression of Serpini1 [9], which augments tumor progression. Cancer cell migration is also enhanced at the same time. In addition, PTEN expression is altered by miR-21 [10] and miR-21 down-regulates PDCD4 expression and thereby contributes to tumor progression and evolution. Not surprisingly, a significant association exists between tumor differentiation and miR-21 expression in gastric tumors [11]. A similar relationship is seen between the TNM stage and the miR-21 levels in circulating tumor cells [12].

It is obvious from the above examples that miR-21 plays a major role in tumor progression in gastrointestinal malignancies.

\section{Disclosure Statement}

The author declares no conflicts of interest.

\section{References}

1 Ozgün A, Karagoz B, Bilgi O, Tuncel T, Baloglu H, Kandemir EG: MicroRNA-21 as an indicator of aggressive phenotype in breast cancer. Onkologie 2013;36:115-118.

2 Yu Y, Kanwar SS, Patel BB, et al.: MicroRNA-21 induces stemness by downregulating transforming growth factor beta receptor 2 (TGFbetaR2) in colon cancer cells. Carcinogenesis 2012;33:68-76.

3 Wang P, Zou F, Zhang X, et al. microRNA-21 negatively regulates $\mathrm{Cdc} 25 \mathrm{~A}$ and cell cycle progression in colon cancer cells. Cancer Res 2009;69:81578165 .

$\checkmark 4$ Horiuchi A, Iinuma H, Akahane T, Shimada R, Watanabe T: Prognostic significance of PDCD4 expression and association with microRNA-21 in each Dukes' stage of colorectal cancer patients. Oncol Rep 2012;27:1384-1392.
5 Chang KH, Miller N, Kheirelseid EA, et al.: MicroRNA-21 and PDCD4 expression in colorectal cancer. Eur J Surg Oncol 2011;37:597-603.

6 Feng YH, Wu CL, Tsao CJ, et al.: Deregulated expression of sprouty2 and microRNA-21 in human colon cancer: correlation with the clinical stage of the disease. Cancer Biol Ther 2011;11:111-121.

7 Nielsen BS, Jorgensen S, Fog JU, et al.: High levels of microRNA-21 in the stroma of colorectal cancers predict short disease-free survival in stage II colon cancer patients. Clin Exp Metastasis 2011; 28:27-38.

8 Feng YH, Wu CL, Shiau AL, et al.: MicroRNA21-mediated regulation of Sprouty2 protein expression enhances the cytotoxic effect of 5-fluorouracil and metformin in colon cancer cells. Int $\mathrm{J}$ Mol Med 2012;29:920-926.
-9 Yamanaka S, Olaru AV, An F, et al.: MicroRNA-21 inhibits Serpini1, a gene with novel tumour suppressive effects in gastric cancer. Dig Liver Dis 2012;44:589-596.

10 Zhang BG, Li JF, Yu BQ, Zhu ZG, Liu BY, Yan M: microRNA-21 promotes tumor proliferation and invasion in gastric cancer by targeting PTEN. Oncol Rep 2012;27:1019-1026.

11 Motoyama K, Inoue H, Mimori K, et al.: Clinicopathological and prognostic significance of PDCD4 and microRNA-21 in human gastric cancer. Int J Oncol 2010;36:1089-1095.

12 Zheng Y, Cui L, Sun W, et al.: MicroRNA-21 is a new marker of circulating tumor cells in gastric cancer patients. Cancer Biomark 2011;10:71-77.

\section{KARGER}

Fax +497614520714

Information@Karger.com

www.karger.com
(C) 2013 S. Karger GmbH, Freiburg

0378-584X/13/0367-0451\$38.00/0

Accessible online at:

www.karger.com/onk
Shailendra Kapoor, M.D.

7487 Sherwood Crossing Place \# 302

Mechanicsville, VA

Tel. +1 865 567-5678

shailendrakapoor@yahoo.com 